\title{
Working Children and Knowledge of Right to Education: A Study of Child Labour in Sabah, Malaysia
}

\author{
Rahimah Abdul Aziz ${ }^{1} \&$ Suriati Iskandar ${ }^{1}$ \\ ${ }^{1}$ School of Social, Development and Environmental Studies, Faculty of Social Sciences and Humanities, \\ Universiti Kebangsaan Malaysia, Malaysia
}

Correspondence: Rahimah Abdul Aziz, School of Social, Development and Environmental Studies, Faculty of Social Sciences and Humanities, Universiti Kebangsaan Malaysia, Malaysia. E-mail: ikra@ukm.my

\author{
Received: February 12, 2013 Accepted: March 29, 2013 Online Published: April 25, 2013 \\ doi:10.5539/ass.v9n8p23 URL: http://dx.doi.org/10.5539/ass.v9n8p23
}

\begin{abstract}
In many countries of the world child labour persists despite the existence and implementation of laws and regulations to eliminate the problem. In many instances children are preferred as workforce because they are easier to manipulate, intimidate, abuse and exploit due in part to their inexperience and relative immaturity. There are many reasons why children work. However, their labour participation means that they are denied or deprived of their right to education, which is crucial to their future prospects, personal development and directly or indirectly to the development of a country. They are not attending school as they should or are not spending enough time on educational development. A study was conducted in 2007-2008 in Tawau, Sabah, Malaysia to determine if the working children are aware of their right to education and if they feel deprived not attending school. It is also to identify reasons they work and if they would return to school if given the opportunity to do so. A total of 26 child labourers aged 9-18 years were sampled and interviewed for the purpose. This paper discusses the findings of the study. From the study it can be concluded that there are many reasons that caused many children to work, which in turn have deprived them of their education. Without education their future would be bleak. This is because only education can help change and improve their lives and their future.
\end{abstract}

Keywords: child labour, child rights, education, Malaysia

\section{Introduction}

In many countries of the world, including Malaysia, the phenomenon of child labour persists despite the existence and implementation of laws and regulations to reduce or even eliminate the problem. The Convention on the Rights of the Child clearly underscores the need to protect children from economic exploitation and from performing any work that is clearly to be hazardous, however child employment continues to prevail in many developing countries (Admassie, 2003:167). Although the exact figures of children working is not known, but in the year 2000, the ILO estimates that “... 246 million child workers aged 5 and 17 were involved in child labour, of which 171 million were involved in work that by its nature is hazardous to their safety, physical or mental health, and moral development. Moreover, some 8.4 million children were engaged in so-called 'unconditional' worst forms of child labour, which include forced and bonded labour, the use of children in armed conflict, trafficking in children and commercial sexual exploitation..." (ILO, 2000). However, in the four-year period between 2000-2004 child labour was seen to have declined about $10 \%$ and then continue to decline by about three percent (3\%) in the four-year period 2004-2008 (ILO, 2010). In many instances children are preferred as workforce because they are easy to manipulate, intimidate, abuse and exploit due in part to their inexperience and relative immaturity.

In Malaysia although the Children and Young Persons Act (Employment) Act 1966 does not encourage the employment of children, studies show that there are children in employment (Jomo, 1992; See, 2007; George, 1992). However, similar with some other countries it is difficult to cite the number of children actually engaged in child labour in Malaysia. In fact very little is known about the actual magnitude, nature and distribution of child labour in the country. This is because little has been done to collect and analyse current relevant data regarding the incidence of child labour in the country. Also official data on child labour is very limited. Furthermore, the Act permits some exceptions such as children are allowed to do light work in family enterprises or as an approved apprentice, although they may not work for more than six (6) hours per day, or six (6) days per 
week or at night. In the Population Census of 1980 it was cited that the number of children between the ages of 10 to 14 years in the work force was 43,000 (Dept. of Statistics, 1983:568). The number declined to 39,746 children in the 1991 Population Census (Dept. of Statistics, 1995:485).

There are many reasons why children work depending on the culture of a society or country, family beliefs, socio-economic conditions among other reasons. There are also many types of child labour including domestic labour, agricultural labour, farm labour, and street workers (vendors, porters and shoeshine). However, their labour participation means that they are denied or deprived of their right to education, which is crucial to their future prospects, personal development and directly or indirectly to the development of a country. They are not attending school as they should or are not spending enough time on educational development. The notion that the children are being exploited and deprived of formal education is a cause for concern for many people. This is because education is regarded as crucial for the children's personal development and future. Also, these children are part of the country's future human capital and as such may have an impact on its future social and economic situations. Even when work does not prevent school attendance, it can have an adverse effect on the children's school performance. Not only those, these children are also deprived of their 'childhood' as they become 'premature adults'. This article discusses the findings of a study conducted among 26 children who are working in the town of Tawau, Sabah, Malaysia. The study, conducted in 2008, was to determine if the children were aware of their right to basic education and if they feel deprived not attending school. It was also to understand why they work and if they would return to school if given the opportunity to do so.

\subsection{Study Area}

Tawau is a port town located on the southeast coast of Sabah (Figures $1 \& 2$ ). It is the third largest port town in Sabah after Kota Kinabalu and Sandakan with a population of approximately 370,000 (Department of Statistics, 2006). The main native ethnic groups in Tawau are Bajau, Suluk, Ida'an and Tidong. There are also a minority of mixed Malay ethnic groups such as Malay, Arab, Bugis. Malay Iban, Malay Jawa, Malay Banjar, Kokos or Bulungan as well as Lun Bawang/Lun Dayeh (Government of Sabah, 1998). The city also has a large ethnic Chinese minority. Also, because Tawau shares its border with Indonesia and the Philippines, the town also receives large numbers of legal and illegal immigrants from these two countries.

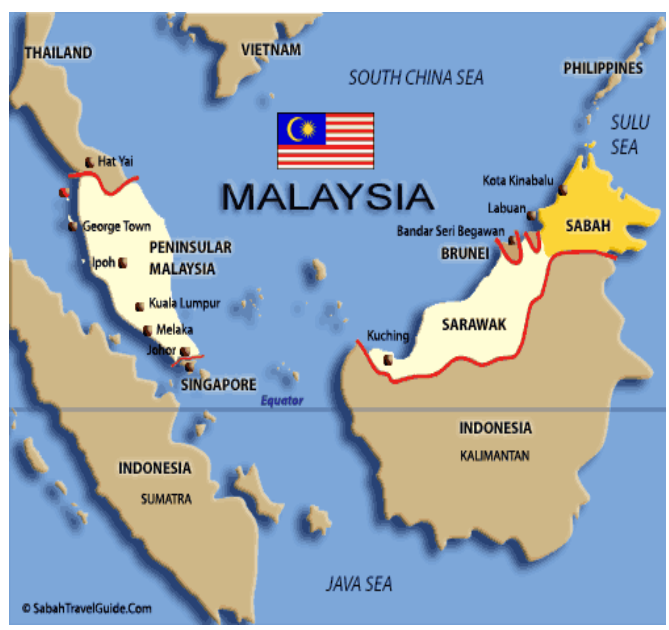

Figure 1. Location of Sabah, Malaysia 


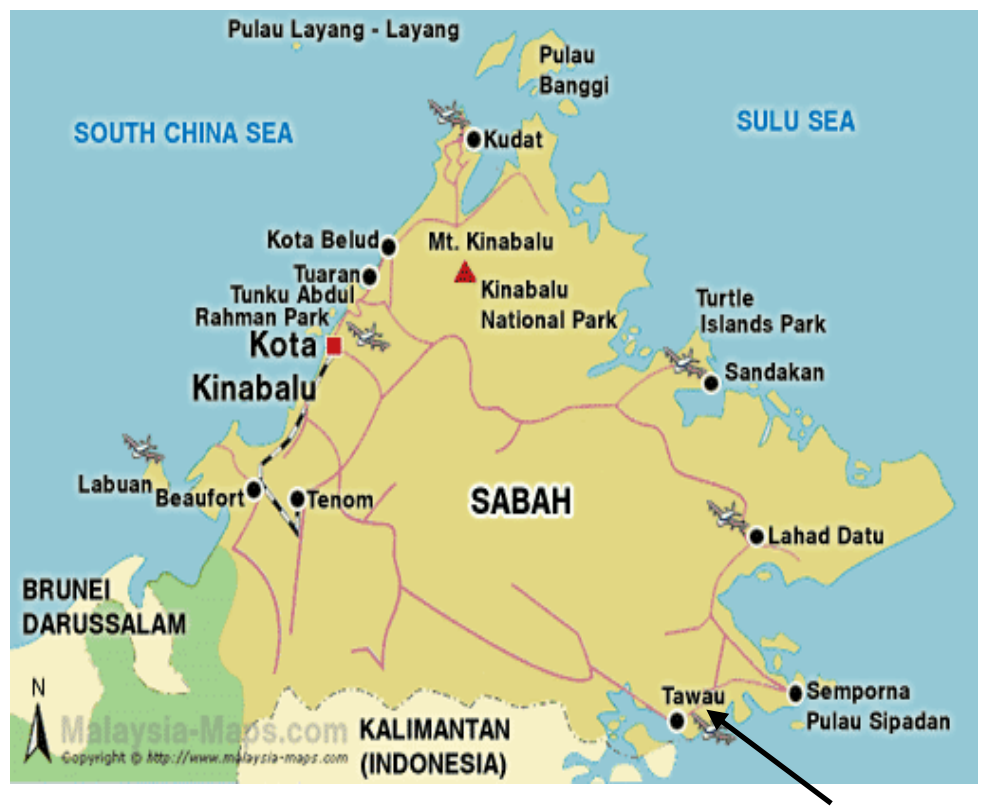

Figure 2. Location of Tawau, Sabah

\section{Method}

The study is about children who are working and as such adopted a purposive sampling approach. This means that only children who are working were sampled. Because the actual population of working children in Sabah in general, and in Tawau in particular, is not easily available only a total of 26 children aged between 9-18 years were sampled using the snowball method. The researcher started with getting a child who was found engaged in a paid activity to agree to an interview. A time and place was agreed upon for the interview to take place, usually not far from the child's workplace. Then, with the help of the first child informant a second working child was identified and introduced to the researcher and so on. During the interview sessions a short questionnaire was administered to record the relevant socio-demographic profile of the children pertaining to such data as their age, gender, birthplace, ethnic background, family background, and education. This was followed by in-depth semi-structured interviews to further probe the issue and gather more information that were not easily captured in questionnaire. Non-participant observation method was also used to observe the surrounding environment where the children were working. Since the number of samples used in the study is small, the study does not claim to be representative of child labour situation in Malaysia in general and in Sabah in particular. However, it could shed some light on the nature of the phenomenon in the country.

\subsection{Child Labour Defined}

Child labour can be found in nearly every economic sector - agriculture, manufacturing, mining and quarrying, domestic service, retail etc. - and especially in the informal sector of the economy. UNICEF has classified child work into three categories:

1) within the family - children are engaged without pay in domestic household tasks, agricultural work, handicrafts/ cottage industries;

2) within the family but outside the home - do work which consists of (seasonal/ fulltime) migrant labour, local agricultural work, domestic services, construction work;

3) outside the family - employed by others, skilled trade (carpet, embroidery etc.), industrial unskilled occupations/ mines, domestic work, commercial work in shops and restaurants, begging, prostitutions and pornography.

There is no universally accepted definition of 'child labour'. Generally, it is taken to mean the employment of children under an age determined by law or custom, that is children start to work before they reach the minimum age for employment. They participate in a wide variety of economic activities in the production of goods and services to earn a living for themselves or for others. In order to enhance its response to effectively eliminate child labour, in 1992 the International Labour Organization's (ILO) created the International Programme on the Elimination of Child Labour (IPEC). ILO-IPEC had defined child labour as “... work situations where children 
are compelled to work on a regular basis to earn a living for themselves and their families, and as a result are disadvantaged educationally and socially..." In other words these children are forced to carry out activities that are normally regarded as adult responsibilities. The work that they do harms or exploits them in some ways physically, mentally, morally or by blocking access to education. Thus, child labour is work that keeps children from attending school. Child labour not only violates a nation's minimum wage laws, but also threatens the children's physical, mental or emotional wellbeing. Child labour is generally regarded as exploitative although some social scientists point out that some kinds of work may be acceptable. In fact in Article 32 of the Convention on the Rights of the Child 1989, the United Nations stipulated that it is,

... the right of child to be protected from economic exploitation and from performing any work that is likely to be hazardous or to interfere in the child's education, or to be harmful to the child's health or physical, mental, emotional, spiritual, moral or social development.

In Malaysia, Section 1A(1) of the Children and Young Persons (Employment) Act 1966 defines a child as ....any person who has not completed his fourteenth year of age or of such age as the Yang di-Pertuan Agong (King) may by notification in the Gazette prescribe... In Malaysia, under the Age of Majority Act 1966, the age of majority is set at 18 years, and there is no law totally banning child labour. When the Children and Young Persons (Employment) Act was passed in 1966, it repealed the Children and Young Persons Ordinance 1947, which had a minimum age of 8 years for working children. The current Act does not have a minimum age.

\subsection{Child's Rights}

There has been a growing attention regarding children's rights, particularly in the last 30 years or so. This growing attention has led to the United Nations Convention on the Rights of the Child (UNCRC) in 1989 to call for protection of children from economic exploitation and from work that threatens their health, education or development (Article 32 of the UNCRC). Generally, it is recognised that children have rights to education, to care from their parents, to rest and relaxation. All of which may be compromised due to the children's involvement with work. They are basically deprived of their childhood, their right to recreate and play and of their natural development. The Convention speaks of rights of children covering four broad areas namely the right to:

1) survival, which includes adequate living standards and access to medical services;

2) development, including education, access to information, leisure and cultural activities, to play, freedom of thoughts, conscience and religion;

3) protection, from all forms of exploitation, abuse and cruelty, arbitrary separation from family and from abuse of the criminal justice system; and

4) participation, including the freedom to express opinions and to be a part of a decision in matters affecting the young person's life.

Malaysia ratified the UNCRC in 1995. This means that the government has the responsibility to make sure that all Malaysian children has all the rights as stated in the Convention, except for the expressed reservations or as long as they do not contravene the Constitution, national laws and national policies of the government.

\section{Results and Discussion}

\subsection{Children's Socio-demographic Background}

Of the 26 children interviewed, nine are girls and 17 boys (Table 1). Their age ranges from 9-18 years with their average being 14.8 years old, which means that if they were in school they would be in the lower secondary level. Majority $(88.5 \%)$ of the children were born in villages located at the periphery of Tawau town, while the rest were born in other areas not too far from the town. 
Table 1. Age and gender of children

\begin{tabular}{cccc}
\hline $\begin{array}{c}\text { Age } \\
\text { (Years) }\end{array}$ & Girls & Gender & Total \\
\hline 9 & - & Boys & 1 \\
10 & 2 & - & 2 \\
11 & 1 & 1 & 2 \\
12 & - & 1 & 1 \\
13 & 1 & - & 1 \\
14 & 1 & 1 & 2 \\
15 & 1 & 3 & 4 \\
16 & 2 & 3 & 5 \\
17 & - & 4 & 4 \\
18 & 1 & 3 & 4 \\
Total & 9 & 17 & 26 \\
\hline
\end{tabular}

Source: Field Data: 2008

It was also found that at the time of the study both parents of $84.6 \%$ of the children were still living. One child had lost both parents and three were then living with their single mothers (Table 2).

Table 2. Status of parents

\begin{tabular}{lcc}
\hline \multicolumn{1}{c}{ Status of parents } & Frequency & $\%$ \\
\hline Both parents alive & 22 & 84.6 \\
Father passed away & 3 & 11.5 \\
Both parents passed away & 1 & 3.8 \\
Total & 26 & 100.0 \\
\hline
\end{tabular}

Source: Field Data: 2008

Although a total of $22(84.6 \%)$ children who were interviewed still have living parents, only 19 were found staying with their respective families, while the parents of the remaining three children are divorced. Of the three children, one child is living with the mother, another with the father, while the third has decided to live with his ageing grandmother. Relatives take care of the orphaned child.

Most of the children are found to come from large families, that is families with between 5-10 children (Table 3), with the average number of children per family being 6-7. Given this background of large families and with low income, it is believed that many families would have allowed a number of their children, especially the older ones, to work to bring some income to the household (Jomo, 1992).

Table 3. Number of children per family

\begin{tabular}{ccc}
\hline Number of children per family & Frequency & $\%$ \\
\hline 2 & 1 & 3.8 \\
3 & 3 & 11.5 \\
4 & 1 & 3.8 \\
5 & 3 & 11.5 \\
6 & 1 & 3.8 \\
7 & 7 & 26.9 \\
8 & 6 & 23.1 \\
9 & 3 & 11.5 \\
10 & 1 & 3.8 \\
Total & 26 & 100.0 \\
\hline
\end{tabular}


Most fathers of these working children are found to be still in employment working as labourers, or engaged in small businesses (mainly petty trading) and one being employed as a driver (Table 4). Majority of the mothers are housewives, while those working are employed either as domestic help, factory worker or are in sales services.

Table 4. Parents' occupation

\begin{tabular}{|c|c|c|}
\hline Types of occupation & Fathers & Mothers \\
\hline Labourers & 20 & \\
\hline Business & 1 & \\
\hline Driver & 1 & \\
\hline Housewives & & 21 \\
\hline Factory worker & & 1 \\
\hline Domestic helper & & 2 \\
\hline Sales & & 1 \\
\hline Total & $22 *$ & $25^{*}$ \\
\hline
\end{tabular}

Note: * 4 fathers and 1 mother had passed away.

$\mathrm{N}=26$

Source: Field Data: 2008

With such occupations, on the average the family income would be between RM700-900 per month (USD218-280). In Malaysia poverty is often measured by referring to the poverty line. In 1999 the poverty line was RM685 (approx. USD215) per month for a household size of 4.9 in Sabah, compared to RM584 (approx. USD185) in Sarawak for a household size of 4.8 and RM510 (approx. USD160) in Peninsular Malaysia for a household size of 4.6 (Eight Malaysia Plan 2001-2005, 2001:62). This shows that the family household income of the children is just hovering around the poverty line and as such is not sufficient for a household of 8-9 people, that is average of 6-7 children plus parents. Inflation would further erode the household's purchasing power. Thus, the children's economic contribution is seen as much needed for the well being of the family.

\subsection{Children and Work}

The children were found to be working in various types of jobs. By virtue of their young age they were not employed in the formal sector, instead they were found to be working in services and petty trading of the non-formal sector. They work as labourers in workshops, at eating-places and other commercial sectors (Table 5). Majority $(77.0 \%)$ of the children indicated that, at the time of the study, they have been working for less than one year, while 19.2\% had been working for between 1-3 years. One child was found to have been working for more than 3 years.

Table 5. Child labour and types of jobs

\begin{tabular}{|c|c|c|}
\hline Types of jobs & Frequency & $\%$ \\
\hline Sales and petty trading & 5 & 19.2 \\
\hline Car wash & 6 & 23.1 \\
\hline Eating-places & 4 & 15.4 \\
\hline Workshop & 1 & 3.8 \\
\hline Carry rice sacks & 1 & 3.8 \\
\hline General Labourers & 9 & 34.6 \\
\hline Total & 26 & 100.0 \\
\hline
\end{tabular}

Source: Field Data: 2008 
Children's involvement in paid activities is a long-standing phenomenon in Sabah. Children have been observed to be working in restaurants, carry goods, work as sales assistants in sundry shops, selling plastic bags outside of the wet market etc. In the study the children were found working in different kinds of jobs based on their gender. The girls worked in restaurants and other eating-places or in sales services. The boys, on the other hand, were engaged in various other types of work. Normally, boys are preferred in more physically demanding jobs. It was also found the most of the older children, that is those aged 15 years and above were involved in the more physically demanding jobs compared to the younger children (Table 6).

Table 6. Age and types of jobs

\begin{tabular}{ccccccccc}
\hline $\begin{array}{l}\text { Age } \\
\text { (Years) }\end{array}$ & Sales & $\begin{array}{l}\text { Car } \\
\text { wash }\end{array}$ & Eating-places & Workshops & $\begin{array}{l}\text { Carry rice } \\
\text { sacks }\end{array}$ & $\begin{array}{l}\text { General } \\
\text { labourers }\end{array}$ & Total & $\%$ \\
\hline 9 & - & 1 & - & - & - & - & 1 & 3.8 \\
10 & 1 & 1 & - & - & - & - & 2 & 7.7 \\
11 & - & 1 & 1 & - & - & - & 2 & 7.7 \\
12 & - & - & - & - & - & 1 & 1 & 3.8 \\
13 & - & - & - & - & - & 1 & 1 & 3.8 \\
14 & 1 & - & - & - & - & - & 1 & 3.8 \\
15 & 1 & 1 & 1 & - & - & 2 & 5 & 19.2 \\
16 & - & 1 & 2 & - & - & 1 & 4 & 15.4 \\
17 & 1 & - & - & 1 & - & 2 & 4 & 15.4 \\
18 & 1 & 1 & - & - & 1 & 2 & 5 & 19.2 \\
Total & 5 & 6 & 4 & 1 & 1 & 9 & 26 & 100.0 \\
\hline
\end{tabular}

Source: Field Data: 2008

In terms of the length of working hours, although the law stipulated that a child should not be made to work for more than six hours a day the study found this was not so. The children are found to have long working hours per day. The data shows that majority of the children work for between 7-12 hours per day. In fact 50.0\% of the children were doing 10-12 hrs per day (Table 7). The long working hours would certainly have an impact on their other activities, particularly their schooling.

Table 7. Number of working hours per day

\begin{tabular}{lcc}
\hline & Number of working hours & Frequency \\
\hline Less than 3 & 1 & 3.8 \\
$4-6$ & 4 & 15.4 \\
$7-9$ & 8 & 30.7 \\
$10-12$ & 13 & 50.0 \\
Total & 26 & 100.0 \\
\hline
\end{tabular}

Source: Field Data: 2008

\subsection{Reasons Children Work}

There are a variety of reasons why children work for a salary, including socio-economic conditions and cultural factors. However, no single factor or reason can fully explain its persistence as the reasons are interlinked with each other. Poverty, lack of social protection and educational opportunity all contribute to the existence and persistence of child labour. Generally, child labour is rooted in poverty although that may not be the only reason why children work. Families on or below the poverty line would 'insist' that their children work to help 
supplement the household income. This is true of the children studied. The reasons that the children gave for working were mainly centred on economic concerns. In the study the main reason that the children gave for working is to help the family cope with their economic situation (Table 8) or to help with the home expenses or in the family's economic activities. Children, especially the older ones, are required to contribute to the family economy, especially when the survival of the family may depend heavily on the cash or in kind contribution of their children (Admassie, 2003:168). To a lesser extent, it is the child's choice to work as a way to exert his/her independence (38.5\%) besides being encouraged by their parents $(7.7 \%)$. This is probably to contribute to the child's training for future work prospect.

Table 8. Reasons for working

\begin{tabular}{lcc}
\hline \multicolumn{1}{c}{ Reasons } & Frequency & $\%$ \\
\hline Help/ support family & 14 & 53.8 \\
By choice/ exert independence & 10 & 38.5 \\
Parents encouragement & 2 & 7.7 \\
Total & 26 & 100.0 \\
\hline
\end{tabular}

Source: Field Data: 2008

Poverty has an obvious relationship with child labour, and studies have shown a ... positive correlation - in some instances a strong one - between child labour and such factors as poverty... (Mehra-Kerpelman, 1996:8). Families need money to survive and children are a source of additional income for the household to satisfy their basic needs. However, poverty is not the only reason. There are other reasons that drive children into employment and none is unique to any one particular country or family. The children had provided other reasons why they work including that they made the choice to work $(11.5 \%)$ and that they wanted to exert their independence (27.0\%). The attitudes of parents also contribute to child labour. Some parents feel that children should work to develop skills that would be useful in the job market, rather than being in schools. This is especially when the family is poor and the children not performing well in school being the added factor. Parents would then not see the benefit of schooling for the 'non-academic inclined' child whom they would then regard as being better off earning a living for the family. Working is also seen as a means of socializing children about their future roles and as a form of training besides helping to put 'food on the table'. In fact parents may think that by working children would not only learn a skill, but also would help supplement the family income.

Another reason that contributes to the number of working children is the demand from the employers who are aware of the advantage of employing children although it would mean going against the law. Children are hired at a fraction of the adult wages and could easily be hired, fired and exploited. Since the children are generally unaware of their rights, they are less likely to complain against these employers.

All the child workers interviewed revealed that they were given monthly wages. As shown in Table 9, majority (76.9\%) of the children receive between RM201-300 per month (USD55-80). As shown by the amount of payment that they received it could be concluded that the children were being exploited. Studies have shown that for the same type of work that the adults do the children are consistently paid less than their adult counterparts. Different from the adults who are formally employed children receive no fringe benefits, insurance or social security (Beqelle \& Boyden, 1988).

Table 9. Wages of child workers

\begin{tabular}{lccc}
\hline & Wages (RM per month) & Frequency & $\%$ \\
\hline Less than 100 & 2 & 7.7 \\
$101-200$ & 1 & 3.8 \\
$201-300$ & 20 & 76.9 \\
$301-400$ & 3 & 11.5 \\
Total & 26 & 100.0 \\
\hline
\end{tabular}

Source: Field Data: 2008 


\subsection{Working Children and Education}

Education is generally recognised as an important human right and the only means to a better future. It is regarded as probably the most effective instrument for combating child labour (Admassie, 2003:171). It would provide a means through which economically and socially deprived children could lift themselves out of poverty in the future. Even if there is no guarantee that education will lead to better life-chances, it is at the very least a necessary condition. The International Labour Organisation (ILO) policy on the minimum age for employment has always been explicitly linked to education, and the Minimum Age Convention stated that the minimum age for entry into employment should not be less than the age of completion of compulsory schooling (ILO, 2000:7). In Malaysia children or young persons is expected to complete their lower secondary compulsory education between the ages of 15 and 16 years, depending on the type of primary school they attended. This means that they should not be starting to work until between the ages of 17 and 18 years and not before.

Labour participation at such young age is believed to affect the children's formal education in one way or another as it would be disrupted. In many cases child labour makes participation in the educational system difficult (Dyer, 2007) as hours spent at work begins to compete with the school activities and make them lose focus on their schoolwork. One could argue that whether work would affect children's school attendance would depend on the type of work activity and the hours spent working. Although there is no strong evidence, there are indications that working at such young age affect children's academic performances as attention to academic activities is reduced. Also, they may have difficulties catching up with their lessons as they have less time for school or may feel physically tired. Consequently, they are often absent from school and subsequently may achieve low grades. More than ever today children need good quality education and training if they are to acquire the skill necessary for them to succeed in the future labour market.

Generally, while many children are attending schools, there are children who are engaged in work activities. Some are also able to combine work with school attendance. Analysis of the findings shows that the children were at different stages of their schooling when they first started working. There are those who were (i) school dropouts, whose natural option is to look for a job (76.9\%); (ii) those who had never attended formal schooling (7.7\%) and (iii) those that were still in schools and only worked before or after school (15.3\%). For those children who worked part-time, they indicated that they had no problem dividing and managing their time between work and school. However, further probing showed that some had been absent from school a few times each month. Although attendance is not sufficient to explain the impact of child labour, it does provide an indirect consequence of child's involvement in labour activities.

\subsection{Knowledge of Rights to Education}

One of the objectives of the study is to determine if the children have knowledge of their right to education. The results of the study shows that the majority of the children (80.8\%) admitted they do not know of their rights, especially their right to education, while only a small percentage of the children said that they know. Due to this lack of knowledge about their rights to education in particular, they are unaware that their right to education have been neglected or compromised because of their involvement in paid activities. In fact, further inquiry showed that some of the children studied did not even know what the term 'right' means or that they even have a 'right'. However, among the children who had dropped out of school (20) or had never gone to school (2), there were those who harbour a desire to return to school or go to school if given the opportunity to do so (Table 10).

Table 10. Desire to return to school if given the opportunity

\begin{tabular}{lcl}
\hline Desire to return/ go to school & Frequency & $\%$ \\
\hline Yes & 14 & 63.6 \\
No & 8 & 36.4 \\
Total & 22 & 100.0 \\
\hline
\end{tabular}

$N=26$

Source: Field Data: 2008

Among the reasons cited for wanting to return to school are that they would be able to make friends, besides being able to pursue their studies. They realise that a good foundation in education would improve future work prospects and thus ensure them a better future than what they are currently experiencing, besides enabling them 
to fulfil their dreams. They recognise the potential benefits of attending school. However, there are also those who do not wish to go back to school even if they have the opportunity to do so. They have chosen to continue working and to 'make money'. These children revealed that school environment had never attracted them. This could be attributed to the failure of the school system to stimulate their interest and curiosity to seek knowledge. Also, it was found that many child workers who did not want to continue schooling were disillusioned and affected by the school assessment of their academic ability. Many believed that they were not good academically and saw no hope of getting through any of the public examinations. Thus, to some extent child work is both the result of leaving school and the reason for leaving school (See, 2007:107).

\section{Conclusion}

Although Malaysia has developed substantially, child labour is still in existence. Cultural factors that are present in the society can, along with the characteristics of the family structure, influence those factors that determine the continued existence of child labour (O'Donnell et al. 2002 in Holgado et al 2012). The child workers are not only found in the agriculture sector and family work, but are also found in the industrial and commercial sectors. The result of the study shows that these children are engaged in paid employment to help themselves and their families to survive, but in the process exposed themselves to exploitative and hazardous situations. And the younger the children start to work the more vulnerable they are to workplace exploitation. In many cases the children do not stay out of school by an act of choice. Poverty, besides other reasons, has caused many children to work. In such a situation work is a necessity, but it in turn deprived them of their education. Thus, to use Ranjan's words (1999) there is an education-child labour trade-off where the children could be on the losing end. This is because by taking on labour-related activities at an early age reduces work opportunities during adulthood despite the belief that it would enhance future work prospect. It would also hinder the achievement of an adequate educational level as the children would have left school at an early age or had not enrolled in school at all due to poverty. Without education their future would generally be bleak. They will continue to live in the vicious circle of poverty. This is because only education can help change and improve their lives and their future. As such measures need to be taken to protect the children's right to education and to a better future.

\section{References}

Admassie, A. (2003, March). Child Labour and Schooling in the Context of a Subsistence Rural Economy: Can They Be Compatible? International Journal of Educational Development, 23(2), 167-185. http://dx.doi.org/10.1016/S0738-0593(02)00012-3

Bequelle, A., \& Boyden, J. (Eds.). (1988). Combating Child Labour. ILO, Geneva.

Department of Statistics. (1983). Population Census 1980. Kuala Lumpur: Department of Statistics Malaysia.

Department of Statistics. (1995). Population Census 1992. Kuala Lumpur: Department of Statistics Malaysia.

Dyer, C. (2007). Working Children and Educational Inclusion in Yemen. International Journal of Educational Development, 27, 512-524. http://dx.doi.org/10.1016/j.ijedudev.2007.02.006

George, M. (1992). Children in Employment in Peninsular Malaysia. In K. S. Jomo (Ed.), Child Labour in Malaysia. Kuala Lumpur: University of Malaya.

Government of Sabah. (1998). Yearbook of Statistics 1998.

Holgado, D., Maya-Jariego, I., Ramos, I., Palacio, J., Oviedo-Trespalacios, O., Romero-Mendoza, V., \& Amar, J. (2012). Impact of Child Labor on Academic Performance: Evidence from Program "Edúcame Primero Colombia". International Journal of Educational Development. http://dx.doi.org/10.1016/j.jjedudev.2012.08.004

International Labour Organisation (ILO). (2000). Every Child Counts. Global Report. Geneva: ILO.

International Labour Organisation (ILO). (2002). A Future without Child Labour. Global Report. Geneva: ILO.

International Labour Organisation (ILO). (2010). Facts on Child Labour 2010. Global Report. Geneva: ILO.

Jomo, K. S. (Ed.). (1992). Child Labour in Malaysia. Kuala Lumpur: University of Malaya.

Lopez-Calva, L. F. (2001). Child Labor: Myths, Theories and Facts. Journal of International Affairs, 55(1).

Malaysia. (1995a). Seventh Malaysia Development Plan 1995-2000. Kuala Lumpur: National Printing.

Malaysia. (1995b). Eighth Malaysia Development Plan 2001-2005. Kuala Lumpur: National Printing.

Mehra-Kerpelman, K. (1996). Children at Work. How many and where? World of Work, 15, 8-9.

Peow, S. H. (2007). The Law and Child Labour in Malaysia. Case study in a Chinese New Village. Kuala 
Lumpur: Pelanduk.

Ranjan, P. (1999). An Economic Analysis of Child Labor. Economic Letters, 64(1), 99-105. http://dx.doi.org/10.1016/S0165-1765(99)00069-5

Rosati, F. C., \& Rossi, M. (2003). Children's Working Hours and School Enrolment: Evidence from Pakistan and Nicaragua. The World Bank Economic Review, 17(2), 283-295. http://dx.doi.org/10.1093/wber/lhg023

Woodhead, M. (1999). Combating Child Labour: Listen to What the Children Say. Childhood, 6, 27-49. http://dx.doi.org/10.1177/0907568299006001003

Xu, Y. B. (2000). Law and Child Labour in Malaysia: A case study in Balakong New Village, Unpublished thesis. University of Malaysia. Kuala Lumpur, Malaysia. 